\title{
13. DINOFLAGELLATE CYST BIOSTRATIGRAPHY OF LATE PALEOCENE AND EARLY EOCENE SEDIMENTS FROM HOLES 552, 553A, AND 555, LEG 81, DEEP SEA DRILLING PROJECT (ROCKALL PLATEAU) ${ }^{1}$
}

\author{
S. Brown and C. Downie, Department of Geology, University of Sheffield ${ }^{2}$
}

\begin{abstract}
Dinoflagellate cysts and other organic-walled microfossils were recovered from samples of late Paleocene and early Eocene age. The samples were dated by means of the informal zonal scheme set up for the Rockall area by Costa and Downie (1979). The assemblages are compared with those from offshore Canada, Greenland, and northwest Europe. In addition the relative percentages of cysts and terrestrial microfossils are used to draw conclusions on the paleoenvironments at the time of deposition. Key species are illustrated along with previously undescribed species.
\end{abstract}

\section{INTRODUCTION}

The Rockall Plateau is a large shallow area in the mid-North Atlantic between western Britain and Iceland (Fig. 1). The overall objective of Leg 81 was to document the structural evolution, changing climate, and ocean circulation over the past 55 m.y. This chapter deals in particular with the earliest post-rift sediments on the western margin of the plateau, from the late $\mathrm{Pa}$ leocene to the early Eocene, and attempts to correlate biostratigraphic events both within the Rockall area and elsewhere.

There are relatively few studies of Paleocene and early Eocene dinoflagellate cysts offshore North Atlantic. Williams (1975) gave an account of the Mesozoic and Cenozoic of offshore eatern Canada, and Williams and Brideaux (1975) examined the upper Mesozoic and Cenozoic of the Grand Banks on the North American continental margin. Soper et al. (1976) and Soper and Costa (1976) examined cyst assemblages of early Tertiary intra-basaltic sediments in East Greenland, and Costa and Downie (1979) set up an informal dinoflagellate cyst zonation based on assemblages from sediments recovered on Leg 48 of the DSDP at Rockall. Manum (1976) examined sediments from the Tertiary of the Norwegian Sea and erected a dinoflagellate zonation. On-shore sections in northwest Europe provide a detailed biostratigraphic framework within which accurate correlation should be possible.

\section{BIOSTRATIGRAPHIC RESULTS}

\section{Hole 555}

The earliest sediments recovered from Hole 555 $56^{\circ} 33.77^{\prime} \mathrm{N}, 20^{\circ} 46.93^{\prime} \mathrm{W}$; water depth $1669 \mathrm{~m}$ ) are mudstones intercalated between basalts and tuffs. Sample $555-94-1,4-8 \mathrm{~cm}$ is the earliest studied here; it con-

\footnotetext{
${ }^{1}$ Roberts, D. G., Schnitker, D., et al., Init, Repts. DSDP, 81: Washington (U.S. Govt. Printing Office).

2 Address: (Downie) University of Sheffield, Mappin Street, Sheffield S1 3JD United Kingdom; (Brown, present address) Paleoservices Ltd., Unit 15 Paramount Industrial Estate, Sandown Road, Watford, United Kingdom.
}

tains Apectodinium hyperacanthum, A. quinquelatum, A. homomorphum, Spiniferites spp., Achomosphaera ramulifera, Areoligera senonensis complex, and Paralecaniella indentata. Of these species only the first three are significant since they all have first occurrences in nannoplankton Zone NP9; $A$. hyperacanthum occurring without Wetzeliella is evidence of late Paleocene age. In this hole, $A$. hyperacanthum occurs between Samples 555-94-1, 4-8 cm, and 86-3, 34-36 cm, without Wetzeliella, thus indicating a probable NP9 age for this interval. It would appear from other cysts which have their first appearance in this interval-i.e., $A$. sumissum (Section 93-2), A. parvum (Section 86-3), and A. augustum (Section 86-3) - that this is the latest part of the Paleocene (Harland, 1979). (See Fig. 2 for species' ranges).

All the assemblages in this interval are dominated by Spiniferites spp., except for Sample 555-86-3, 34-36 cm, which is dominated by Apectodinium spp. This interval is equivalent to Zone Ia of Costa and Downie (1979).

Between Cores 85 and 67, there is a thick sequence of basalts and volcanic breccias. Directly above this there is an interval up to and including Core 46 in which many reworked dinoflagellate cysts are present (Palaeohystrichophora sp., Nannoceratopsis sp., Aptea sp., Odontochitina operculata, Chatangiella sp., Palaeoperidinium pyrophorum, and P. basilium). These species are derived from rocks of various ages from Mid-Jurassic-Danian.

The first occurrence of Spinidium? sp. A. (Costa and Downie, 1979) is in Core 65, Section 1; this species has a range restricted to Zones Ia and the lower part of $\mathrm{Ib}$ (Costa and Downie, 1979). Wetzeliella astra occurs for the first time in Section 61-5. This species has been used (Costa et al., 1978) as a marker for the basal Eocene, and the W. astra zone of northwest Europe (Costa et al., 1978 ) is equated with Zone Ial of Rockall (Costa and Downie, 1979). Other species which occur for the first time in the interval up to Core 45 are known to have first occurrences in the Paleocene in other areas, e.g., Adnatosphaeridium multispinosum and Dapsilidinium pastielsii.

The assemblages in this interval are once again largely dominated by Spiniferites spp. except in Section 60-3, 


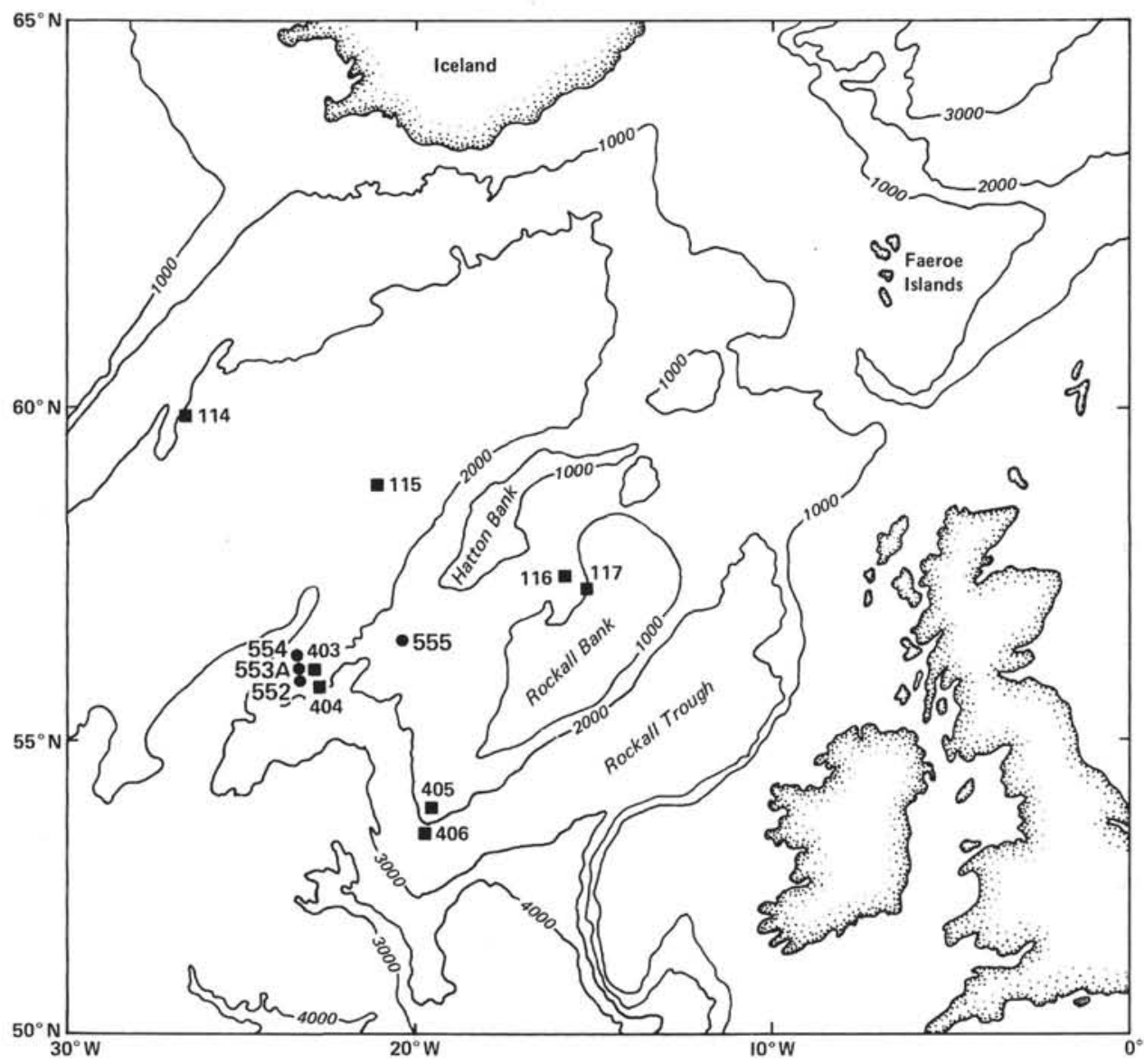

Figure 1. Location of DSDP sites in the Rockall area.

where Apectodinium spp. and Wetzeliella astra dominate, and Section 47-4 in which Spinidinium? sp. A becomes dominant. Although $W$. astra is found continuously in Cores 61,60 , and 59 , it occurs again higher in the sequence in Core 45. This discontinuous distribution may be a result of ecological factors, since the percentage of cysts compared with pollen and spores drops dramatically in the interval between the two occurrences.

Costa and Downie (1979) defined the base of Zone Ib by the first occurrence of Wetzeliella meckelfeldensis. In Hole 555, this occurs for the first time in Section 32-4, the last productive sample obtained from this hole. The gap between the last occurrence of $W$. astra and the first occurrence of $W$. meckelfeldensis spans a period where pollen and spores are dominant in the assemblages; since no members of the Wetzeliellaceae are present in this interval the placing of a boundary between the two zones is somewhat problematical. Assemblages in this interval are once again largely dominated by Spiniferites spp. but other genera do become dominant at times. In Section 44-2, Millioudodinium guiseppei dominates the assemblage, and in Section 42-4, Operculodinium centrocarpum is the dominant cyst. Towards the top of the sequence ? Senegalinium cf. obscurum dominates the assemblage in Section 33-6. One interesting phenomenon is the complete absence of dinoflagellate cysts from Sec- tion 37-1; here pollen and spores dominate and Pediastrum sp. forms $4 \%$ of the assemblage.

Comparison of the assemblages from Hole 555 with other areas allows correlation with the upper intrabasaltic sediments of the Blosseville Basalts of East Greenland (Soper et al., 1976). These appear to span the Paleocene/Eocene boundary. The lowest dated assemblage of the sequence is referable to the Apectodinium hyperacanthum Zone (Costa and Müller, 1978), and the upper dated assemblage relates to the Wetzeliella meckelfeldensis Zone. These zones correlate with Zones Ia and Ib (Costa and Downie, 1979) although the thick basalt sequence obscures Zone Ial (the W. astra zone of Europe). The sequence of basalts in Hole 555 is bounded by the same dinoflagellate cyst Zones Ia and Ib, although Zone Ial does occur.

The sequences of basalts in Greenland and also in Hole 555 were formed during a period of rifting prior to the onset of the generation of oceanic crust. The separation of the Rockall microcontinent from Greenland is believed to have taken place approximately $52 \mathrm{~m}$.y. ago.

The occurrence of the $W$. astra and $W$. meckelfeldensis zones in Hole 555 indicates a correlation between Zones Ial and $\mathrm{Ib}$ and the lower London Clay of the Hampshire and London basins. In addition to the previously mentioned zone fossils, many other cysts are common to the assemblages of Hole 555 and the lower Lon- 


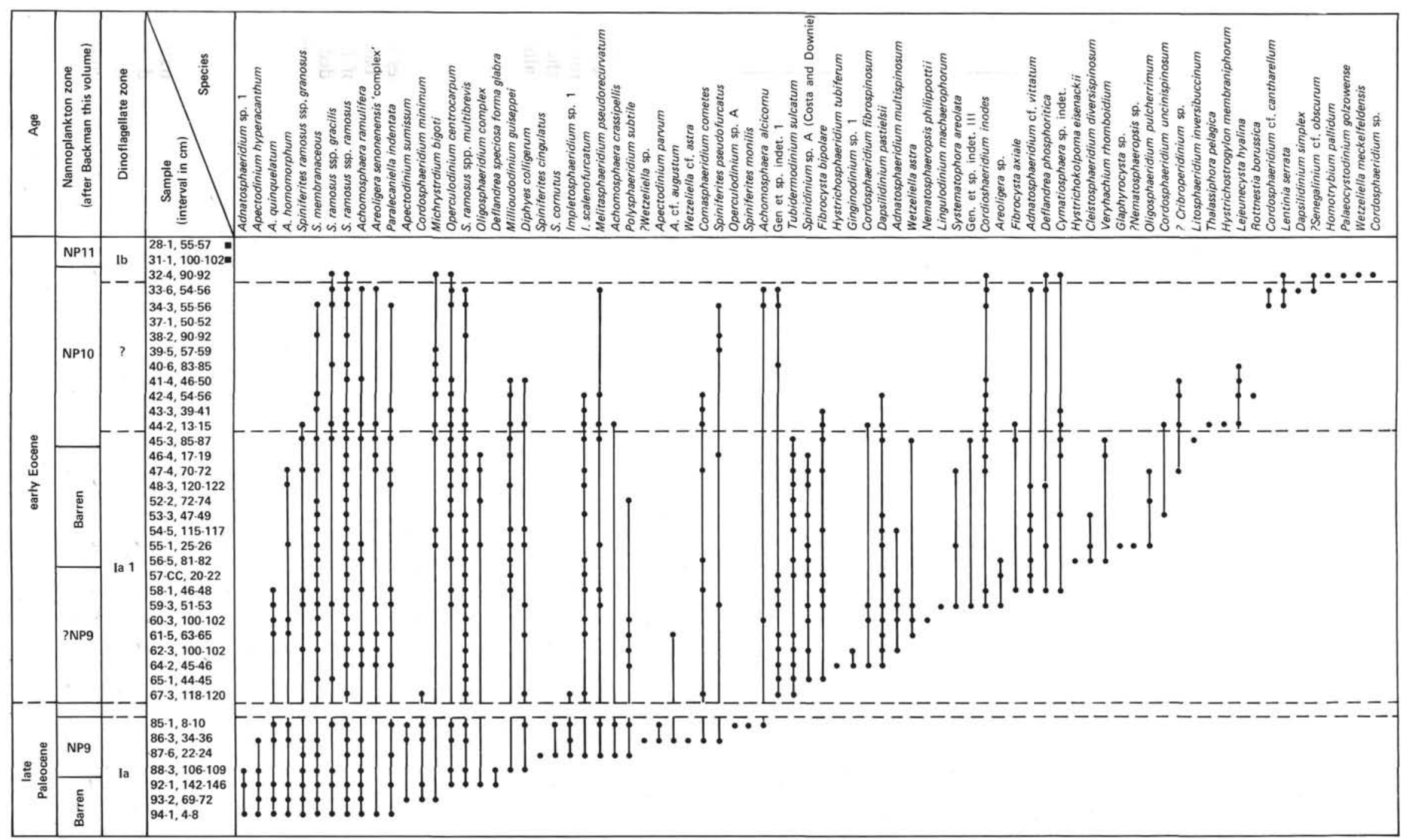

Figure 2. Dinoflagellate biostratigraphy, Hole 555. 
don Clay (Zone LC1, Bujak et al., 1980) (see Fig. 2). This is also true for north Germany, where many species recovered by Gocht (1969) from the 'Unter-Eozän' 1 + 2 are also found at Rockall.

Assemblages from the Norwegian Sea described by Manum (1976) from the early Eocene (Zones VIIa and VIIb) appear to have very few species present, none of which are particularly useful for dating. However, Zone VIIa of Manum is marked by the first appearances of Glaphyrocysta ordinata and Thalassiphora pelagica. The former appears for the first time in Zone LC1 (Bujak et al., 1980) and the latter in late Zone Ia at Rockall (Costa and Downie, 1979). Thus a tentative correlation may be made between the upper part of Hole 555 and the lowest zones in the Norwegian Sea.

A comparison with the zones of Williams and Bujak (1977) shows that although many of the same species were present in both areas, during the late Paleocene and early Eocene, the dominants in the assemblages were quite different, and this precludes closer correlation of the two areas on the available evidence.

\section{Hole 553A}

The lower part of Hole $553 \mathrm{~A}\left(56^{\circ} 05.32^{\prime} \mathrm{N}, 23^{\circ}\right.$ 20.61' W; water depth 2339 m; Fig. 3) is characterized by a lack of stratigraphically useful dinoflagellate cysts. However, some correlations may be indicated by the local ranges of certain species.

Senegalinium cf. obscurum occurs from the bottom of Hole 553A up to Core 24, Section 2. In Hole 555 this species occurs only in Cores 32 and 33, however the correlations based on calcareous nannoplankton (Backman, this volume) rule out a correlation by means of $S$. cf. obscurum. In both Hole 553A (Core 36) and Hole 555 (Core 33) this species becomes dominant, the assemblages contain more than $50 \%$ dinoflagellate cysts, and they indicate that conditions were quite marine. It would seem likely that the ecological requirements of $S$. cf. obscurum strictly control its distribution, since it only occurs in transgressive phases. In the preceding assemblages in both holes Spiniferites spp., a genus known to favor more inshore conditions (Wall et al., 1977), were dominant.

An interval where pollen and spores make up $100 \%$ of the assemblage is present in Section 26-1. Above this horizon is an interval where the only stratigraphically significant cyst is Spinidinium? sp. A. (Costa and Downie). This becomes dominant in Section 22-1; its range quoted by Costa and Downie (1979) is throughout Zone Ia and the lower half of Zone Ib. On the basis of this range the youngest age for Section 14-1 is early NP11 (Costa and Müller, 1978). The next horizon in Hole $553 \mathrm{~A}$ for which a good date can be given is Section 12-4, in which Dracodinium condylos occurs. This species has a range in the Eocene of southern England restricted to Zones LC3-B1 of Bujak et al. (1980). Costa and Downie (1979) place the first occurrence of $D$. condylos at the base of Zone II in the Rockall area. The contemporaneous appearance of Dracodinium similis, Phthanoperidinium echinatum, and Eatonicysta ursulae confirms the Zone II age of the interval between Sections $12-4 \mathrm{~cm}$ and 11-1. In the latter section Kisselovia edwardsii occurs for the first time; this may be an indication of a basal Zone III age, correlating with the Kisselovia coleothrypta zone of northwest Europe (Costa and Downie 1976). This zone is thought to correlate with upper NP12, lower NP13 (Costa and Müller, 1978). All samples above Core 11 were barren.

Although a wide variety of species were recovered, none of those occurring below Section 12-4 allows a precise date to be given for the sediments. The local first occurrence of Fibrocysta bipolare may have a possible bearing on the correlation of Holes 555 and 553A. In Hole $555 \mathrm{~F}$. bipolare occurs for the first time just above the thick basalt horizon separating Cores 67 and 85 . Its first occurrence in Hole 553A is in Section 37-5, at the bottom of the hole. This makes it highly unlikely that the sediments at the base of the hole are any older than Zone Ial.

The dinoflagellate cyst assemblages of Zones II and ?III in Hole 553A show more variation in terms of the dominant cyst species than do the assemblages of Zones ?Ia1 and ?Ib. In Sample 553A-11-4, 142-144 cm, D. condylos is dominant. And in Sample 553A-11-1, 7374 , Homotryblium tenuispinosum dominates an assemblage, with over $90 \%$ dinoflagellate cysts showing a major change to more oceanic influenced conditions; this is supported by the increased abundance of Impagidinium patulum.

Zone II in Hole 553A would appear to correlate with the lower sequence of the Kap Dalton sediments of East Greenland (Soper et al., 1976) and also with the upper London Clay. Costa and Downie (1979) note that the environment at Rockall in Zone II was probably a fluctuating shelf environment. This is based on the variability of the pollen/plankton ratio, the dominance of dinoflagellate cysts over pollen and spores, and the composition of the dinoflagellate assemblages. These observations made about the material from Sites 404 and 405 also hold true for the assemblages of Zone II age from Hole 553A.

\section{Hole 552}

The samples taken from Hole $552\left(56^{\circ} 02.56^{\prime} \mathrm{N} ; 23^{\circ}\right.$ $13.88^{\prime} \mathrm{W}$; water depth $2301 \mathrm{~m}$ ) produced very rich assemblages of dinoflagellate cysts; percentages of pollen and spores never reach more than $35 \%$ (Fig. 4 gives details of species present). Terrestrial organic debris is very sparse and, in conjunction with the other factors, indicates a relatively distant shoreline at the time of deposition. The presence of Dracodinium condylos in the lowest sample (Sample 552-18-2, 10-13 cm) indicates an earliest age of basal Zone II (correlated with NP12, Costa and Müller, 1978). Costa and Downie (1979) note that the base of Zone III is characterized by assemblages dominated by Polysphaeridium zoharyi; in Hole 552 this datum occurs in Section 16-1, where $P$. zoharyi makes up over $60 \%$ of the assemblage.

An assemblage referable to Zone IVa does not occur in Hole 552; however, Costa and Downie (1979) indicate that this interval is either eroded or represented by condensed barren samples at Sites 403 and 404 . These two 


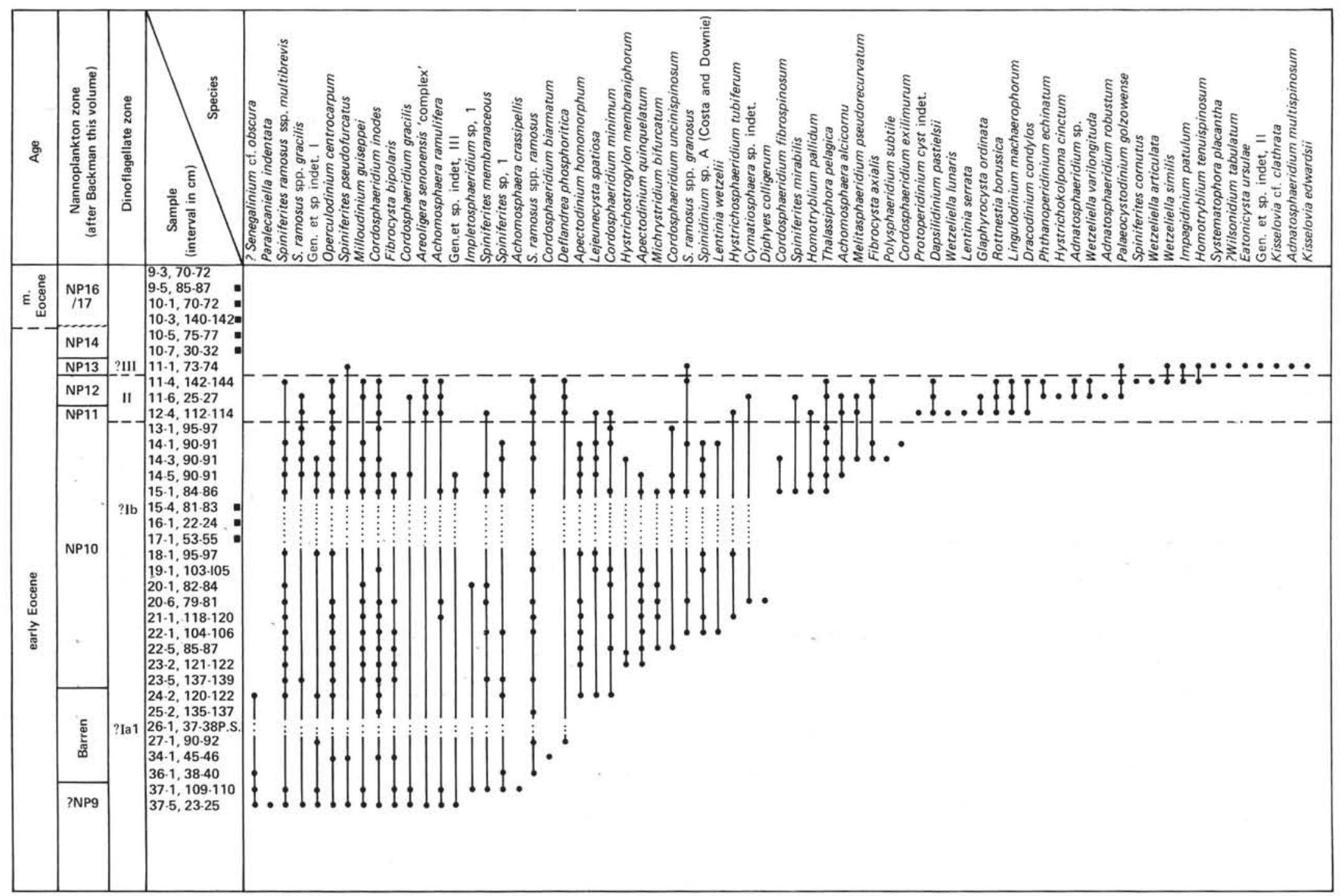

Figure 3. Dinoflagellate biostratigraphy, Hole 553A. 


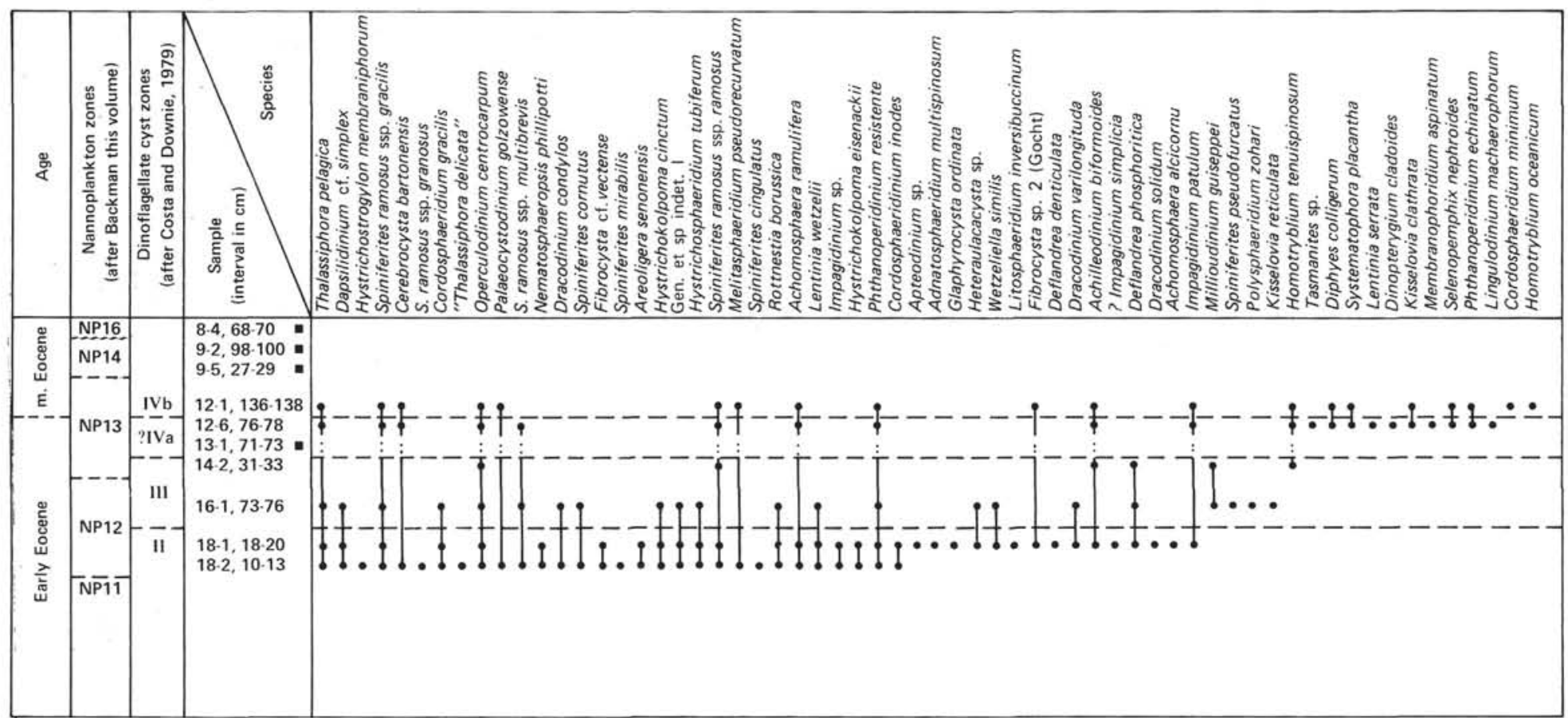

Figure 4. Dinoflagellate biostratigraphy, Hole 552. 
sites from Leg 48 are the nearest to Site 552 and indicate that the barren interval in Core 13 may represent Zone IVa.

Zone IVb is marked by the incoming of a number of species including Homotryblium oceanicum. This species first occurs in Section 12-1 in Hole 552, and this horizon is taken to be the base of Zone IVb. Above this sample the remaining cores are barren. The assemblages from Hole 552 show a range of dominant species. The two samples from Core 18 are dominated by Operculodinium centrocarpum. Shortly thereafter in Core 16, at the base of Zone III, Polysphaeridium zoharyi becomes dominant. In the upper part of Hole 552, in Core 12, the two samples examined are dominated by Thalassiphora pelagica. The various forms of this species described by Benedek and Gocht (1981) are all present in the assemblages to varying degrees, but the ecological significance of this is not yet apparent. Costa and Downie (1979) relate the changes of dominant species in Zones III, IVa, and IVb to possible instability in the pattern of oceanic currents; however other factors may be equally important in determining the species composition of assemblages-as shown by Wall et al. (1977).

\section{ENVIRONMENTAL INTERPRETATION OF PALYNOLOGICAL ASSEMBLAGES}

Methods for interpreting the assemblages found in this study fall into two categories. The first is to use a ratio of pollen and spores to dinoflagellate cysts, which simply assumes that the farther offshore one goes the fewer pollen and spores one will find in the sediment. This is largely the subject of Muller's (1959) paper on the palynology of recent sediments near the Orinoco delta. He found that the amount of pollen deposited decreased away from the delta and that prevailing winds and currents determined the rate of decrease. The distribution of the dinoflagellate cysts showed a general increase offshore with few or no cysts near the shoreline.

The second method is to use the present ecological requirements of cyst species known to occur both in the early Tertiary and through to the present day. Wall et al. (1977) published the most detailed paper to appear in recent years on the subject of dinoflagellate cyst distributions, and the findings of that paper are used here to interpret the paleoenvironment at the time of deposition. Naturally this method has serious drawbacks, the principal one being that many abundant or dominant species of the early Eocene have since become extinct. Genera such as Apectodinium, Wetzeliella, and Kisselovia are thought to be extinct members of the Peridinaceae. As such it may be possible that their ecological requirements were similar to modern species of Peridinium, but this must be regarded with great caution.

The accumulation of cysts as the sediments were deposited has led to an averaging of the cyst record, since minor fluctuations resulting from short-term variations in local conditions are obliterated by the sample thickness which may represent hundreds or thousands of years. One result of this phenomenon is to give more significance to the overall trends displayed in the assemblages.
Figure 5 shows the percentages of dinoflagellate cysts present in each sample along with the number of cyst species. The number of species present is a rough guide to the type of environment. Maximum diversity appears to occur in the shelf environment (based on the type of cysts present) while the least diversity occurs in the estuarine environment. The percentages of cysts present in each sample are an indication of distance from shoreline. In combination with the environmental inferences drawn for various groups of species by Wall et al. (1977), there appear to be two major environments represented in the data from this study. The first is the estuarine environment, usually found with a high percentage of pollen and spores along with large pieces of organic detritus. The dinoflagellate cyst assemblages in this environment have a low species diversity and a low total percentage, usually less than $30 \%$. The dominant cyst species are always Spiniferites spp. Occasionally the freshwater alga Pediastrum occurs in small numbers.

Secondly, there is the shelf environment, where the organic debris present is much less and always occurs in very small fragments. Pollen and spores make up a much smaller percentage of the assemblage, usually between $10 \%$ and $60 \%$ according to the distance from the shore. Spiniferites spp. are still present but usually the dominant form is Operculodinium centrocarpum. Occasionally in the lower zones, Apectodinium, Wetzeliel$l a$, and Spinidinium dominate in this environment.

Wall et al. (1977) stated that Impagidinium spp. increased steadily with distance from shore until they became dominant in oceanic conditions. Since Impagidinium does not become dominant in any sample, it is assumed here that full oceanic conditions did not occur at any of the Leg 81 sites during the interval from Zones Ia-IVb. The highest numbers of this genus were recorded from Zones ?IVa and IVb, but in these samples Thalassiphora pelagica dominates.

The palynological analysis reveals that during the entire late Paleocene and early Eocene the local conditions on the southwest margin of Rockall fluctuated between estuarine and outer shelf environments. Other organicwalled microfossils present in the assemblages in addition to pollen and dinoflagellate cysts tend to confirm the ecological conclusions drawn from those groups. The occurrence of Pediastrum sp. always coincides with the more estuarine conditions. This freshwater alga is often found in sediments associated with estuarine conditions - probably as a result of being flushed from the freshwater environment. The occurrence of foraminiferal test linings also shows a distinct distribution pattern. These are generally found in larger numbers in the shelf assemblages-reaching a peak in Hole 552, Section 126 , where they make up $17 \%$ of the assemblage. The trend observed in this study is to greatly increased abundance on the outer shelf. Muller (1959) indicated that their abundance increases seawards in the modern sediments of the Orinoco Delta.

Evidence from heavy mineral analysis of Hole 555 (Morton, this volume) shows an alternation between Greenland-derived sediment and Rockall-derived sediment. A comparison of this data with the pollen and 


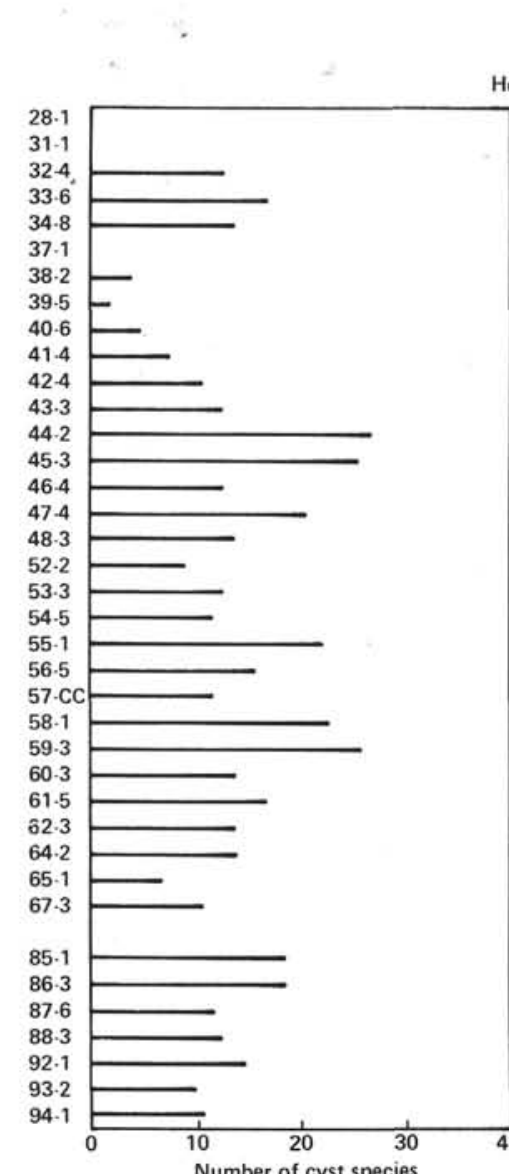

Number of cyst species
Hole 555

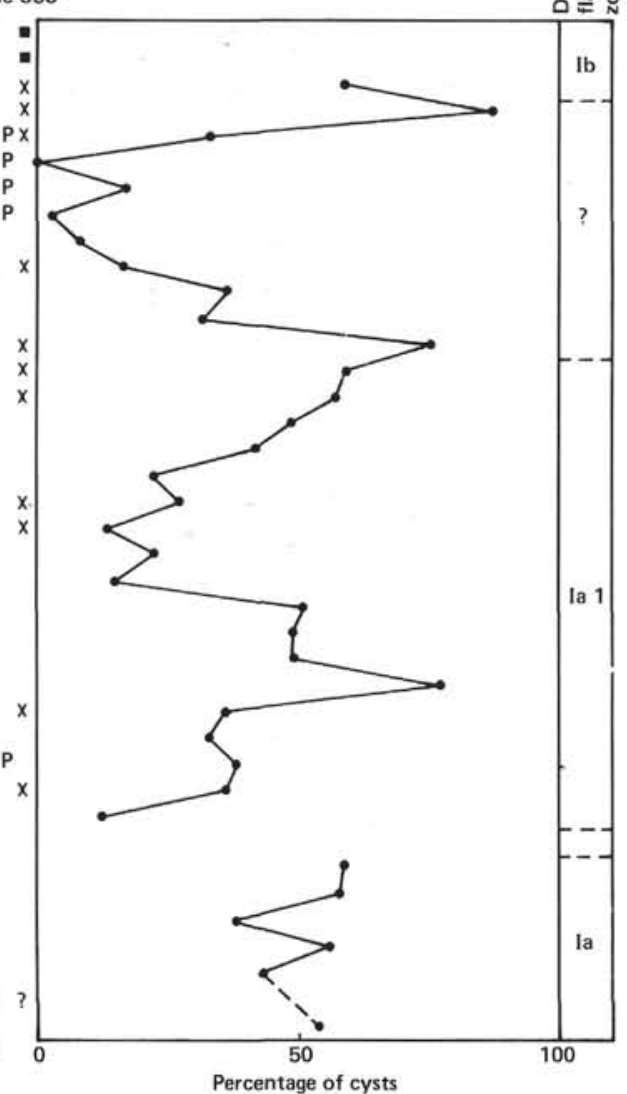

- Barren samples

Insufficient palynomorphs for statistical analysis

$X$ Foraminiferal test lining present in assemblage

$P$ Pediastrum occurring in small percentages

Note: Dinoflagellate zones (Costa and Downie, 1979)

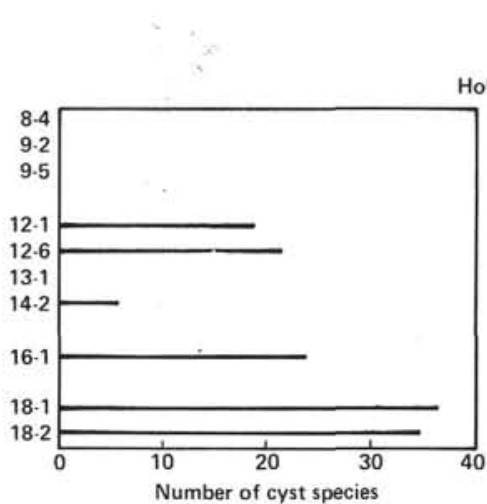

Hole 552

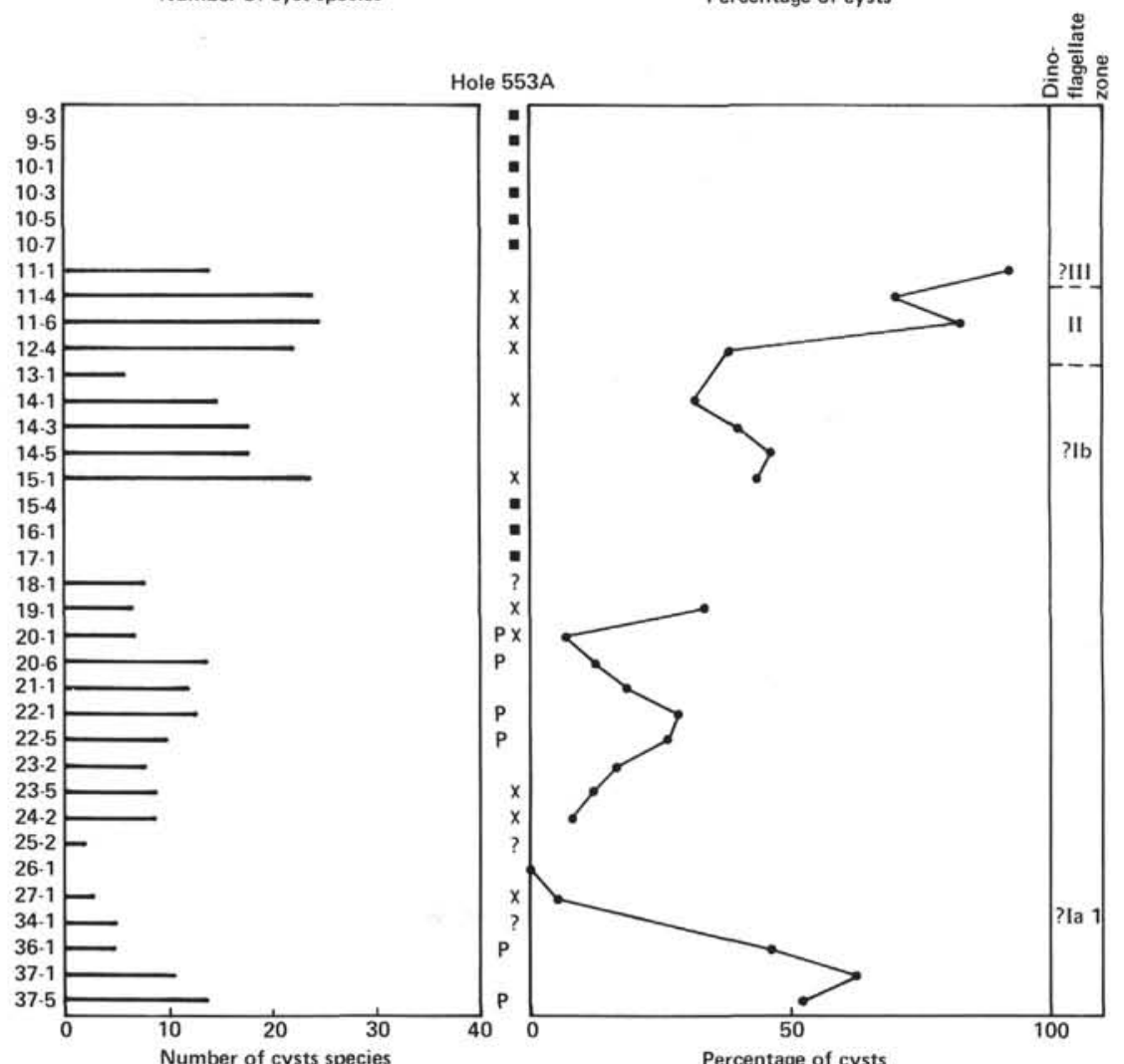

Figure 5. Dinoflagellate species diversity and relative percentages of cysts and pollen and spores. (All percentages are based on a count of 250 palynomorphs, and species numbers were obtained by scanning five slides.) 
spore percentages shows that the Greenland-derived sediment is represented by intervals of high pollen and spore values, whereas Rockall-derived sediment is characterized by lower pollen and spore percentages. It appears that the sediment source area was controlled by regression and transgression-a minor transgression being sufficient to bring about the cessation of sediment supply from Greenland.

\section{CONCLUSIONS}

The palynological assemblages recovered from Holes $552,553 \mathrm{~A}$, and 555 were in general quite rich; occasional barren samples occurred in the sequence.

Most assemblages contained both dinoflagellate cysts and pollen, whereas the occurrence of Pediastrum and foraminiferal test linings was sporadic. The amount of terrestrial organic debris varied considerably from sample to sample, but the greatest amounts occurred in Zones Ia-Ib; this is also true of the holes drilled on Leg 48 (Costa and Downie, 1979). As has been noted, a combination of heavy mineral analysis and pollen and spore percentages indicate a series of minor transgressions in Zones Ia and Ial; however, the variations in pollen and spore percentages are of much lower amplitude at Sites 403, 404, and 553A. These sites lie to the south of Site 555 and appear to indicate that the transgression had a greater effect in the north of the area. This could be confirmed by detailed study of Site 117 .

The greatest accumulation of lavas at Site 555 occurred between Cores 67 and 85 . This interval is bounded by Zone Ia at the base and Zone Ial at the top. Studies of the dinoflagellate cysts from intrabasaltic sediments in East Greenland (Soper et al., 1976) reveal that the main basalt sequence is bounded by the $A$. hyperacanthum Zone at the base (equivalent to Ia) and the $W$. meckelfeldensis Zone at the top (equivalent to Ib). Thus a correlation can be made between the Greenland sequence and the lavas erupted at Site 555. It is apparent that these eruptions coincide with the Paleocene/Eocene boundary (based on dinoflagellate cysts).

It is interesting to note that the Mo-Clay formation in Denmark, which contains a tuff horizon and a series of volcanic ash layers, is also bounded by the $A$. hyperacanthum Zone at the base and the $W$. meckelfeldensis Zone at the top (Hansen, 1979).

The dating of samples in this study was achieved largely by comparison with the zones of Costa and Downie (1979); however, zonal boundaries are difficult to define in some cases because critical dinoflagellate cyst genera, such as Wetzeliella, are missing from the assemblages. It is assumed that this is a result of environmental fluctuations (indicated by changing percentages of the various palynomorph groups). Despite this factor, it has been possible to demonstrate the presence of Zones Ia-IV.

A comparison of the pollen and spore to dinoflagellate ratios from this study with those of Costa and Downie (1979) shows a great deal of similarity. At Sites 403 and 404 they found very high percentages of pollen and spores with minor fluctuations in Zones Ia and Ib (Zone Ial was not identified at these sites). At Holes 555 and
553A there are peaks of dinoflagellate cysts, not found at Sites 403 and 404, occurring in Zone Ial. In the appendix to their 1979 paper, Costa and Downie examined the cyst assemblages from Hole $117 \mathrm{~A}$. This site was apparently richer in dinoflagellates, with less terrigenous influence in Zones Ia and Ial. However, no percentage values are given for the proportion of cysts to pollen, which only allows speculation that Holes 555 and $553 \mathrm{~A}$ are nearer in the character of their assemblages to Hole 117A than to Sites 403 and 404.

Holes 405 and 552 are very similar in terms of the low percentages of pollen and spores which persist from Zones II-IV. This indicates that both sites had a greater oceanic influence during this interval. It would seem that there is a high level of similarity between the results of this study and those of Costa and Downie (1979).

Using dinoflagellate cysts, the correlation of the northwest European deposits by Costa and Downie (1976) and Costa et al. (1978) can be extended to Rockall as shown by Costa and Müller (1978). These links become more tenuous after the early Eocene, probably as a result of changing circulation patterns brought about by the continued spreading of the North Atlantic.

This study has shown that while it is clearly possible to correlate the sedimentary sequence at Rockall to the European mainland, the Canadian offshore sequences are not at all easily correlated with Rockall. This is because of the absence of a considerable number of diagnostic species and the different nature of the assemblages. The environment of deposition of the late Paleocene and early Eocene sediments at Rockall has been shown, by a combination of dinoflagellate cyst species and cyst-pollen ratios, to have varied between outer shelf and inshore to estuarine environments.

\section{ACKNOWLEDGMENTS}

The authors would like to thank the National Science Foundation for the samples received from Leg 81 . Thanks are also due to Dr. Andy Morton for information on the heavy minerals from Leg 81 .

\section{REFERENCES}

Benedek, P. N. V., and Gocht, H., 1981. Thalassiphora pelagica (Dinoflagellata, Tertiär): Elektronenmikroskopische untersuchung und gedanken zur paläobiologie. Palaeontographica, 180B; 39-64.

Bujak, J. P., Downie, C., Eaton, A. L., and Williams, G. L., 1980. Dinoflagellate cysts and acritarchs from the Eocene of southern England. Spec. Pap. Palaeontol., 24:1-100.

Costa, L. I., and Downie, C., 1976. The distribution of the dinoflagellate Wetzeliella in the Palaeogene of northwestern Europe. Palaeontology, 19:591-614.

1979. Cenozoic dinocyst stratigraphy of Sites 403 to 406 (Rockall Plateau), IPOD, Leg 48. In Montadert, L., Roberts, D. G. et al., Init. Repts. DSDP, 48, Pt. 1: Washington (U.S. Govt. Printing Office), 513-529.

Costa, L. I., Denison, C. N., and Downie, C., 1978. The Paleocene/ Eocene boundary in the Anglo-Paris Basin. J. Geol. Soc. London, 135:261-264.

Costa, L. I., and Müller, C., 1978. Correlation of Cenozoic dinoflagellate and nannoplankton zones from the N.E. Atlantic and N.W. Europe. Newsl. Stratigr., 7(2):65-72.

Gocht, H., 1969. Formengemeinschaften altertertiären microplanktons aus bohrproben des erdölfeldes meckelfeld bei Hamburg. Palaeontographica, 126B:1-100.

Hansen, J. M., 1979. Age of the Mo-Clay formation. Bull. Geol. Soc. Denmark, 27:89-91. 


\section{S. BROWN, C. DOWNIE}

Harland, R., 1979. The Wetzeliella (Apectodinium) homomorpha plexus from the Palaeocene/earliest Eocene of North-West Europe. Proc. 4th Int. Palynol. Conf., Lucknow (1976-77), 2:59-70.

Manum, S. B., 1976. Dinocysts in Tertiary Norwegian-Greenland Sea sediments (DSDP Leg 38) with observations on palynomorphs and palynodebris in relation to environment. In Talwani, M., Udinstev, G., et al., Init. Repts. DSDP, 38: Washington (U.S. Govt. Printing Office), 897-919.

Muller, J., 1959. Palynology of Recent Orinoco delta and shelf sediments: Reports of the Orinoco Shelf expedition. Micropalaeontology, 5(1):1-32.

Soper, N. J., Downie, C., Higgins, A. C., and Costa, L. I., 1976. Biostratigraphic ages of Tertiary basalts on the East Greenland continental margin and their relationship to plate separation in the northeast Atlantic. Earth Planet. Sci. Lett., 32:149-157.

Soper, N. J., and Costa, L. I., 1976. Palynological evidence for the age of Tertiary basalts and post-basaltic sediments at Kap Dalton, Blosseville Kyst, Greenland. Grons. Geol. Unders. Rp., 80:123-127.
Wall, D., Dale, B., Lohmann, A. P., and Smith, W. K., 1977. The environmental and climatic distribution of dinoflagellate cysts in modern marine sediments from regions in the North and South Atlantic Oceans and adjacent seas. Mar. Micropalaeontol., 2:121-200.

Williams, G. L., 1975. Dinoflagellate and spore stratigraphy of the Mesozoic-Cenozoic offshore eastern Canada. Geol. Surv. Canada Pap. 74-30, 30:107-163.

Williams, G. L., and Brideaux, W. W., 1975. Palynologic analyses of upper Mesozoic and Cenozoic rocks of the Grand Banks, Atlantic continental margin. Geol. Surv. Canada Bull., 236:1-163.

Williams, G. L., and Bujak, J. P., 1977. Cenozoic palynostratigraphy of offshore eastern Canada. In Elsik, W. C. (Ed.), Contributions to Stratigraphic Palynology (Vol. 1). Am. Assoc. Strat. Palynol. Contribu. Ser. 5A.

Date of Acceptance: Feburary 9, 1983 

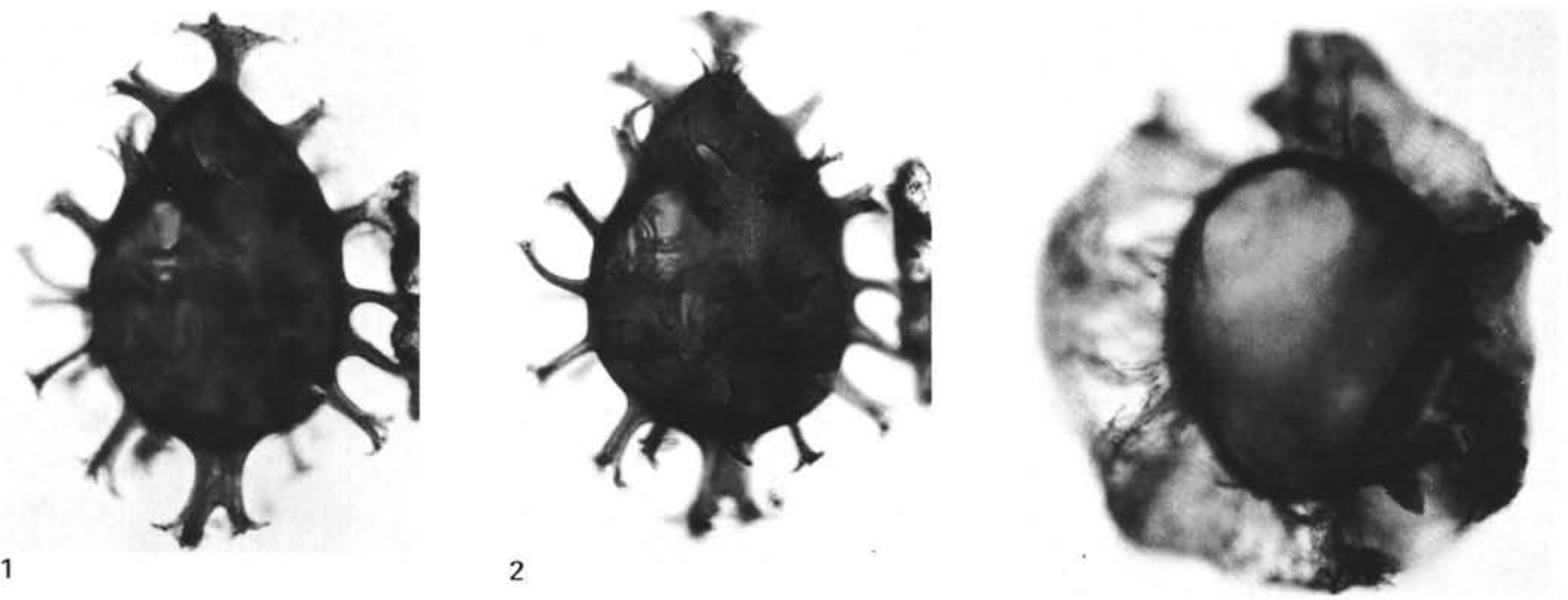

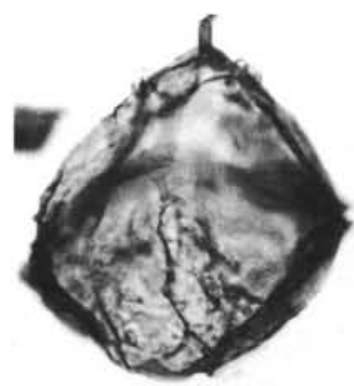

4

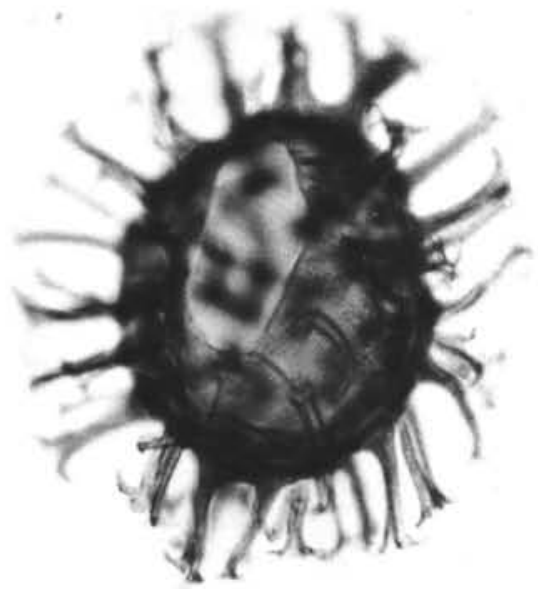

8

5
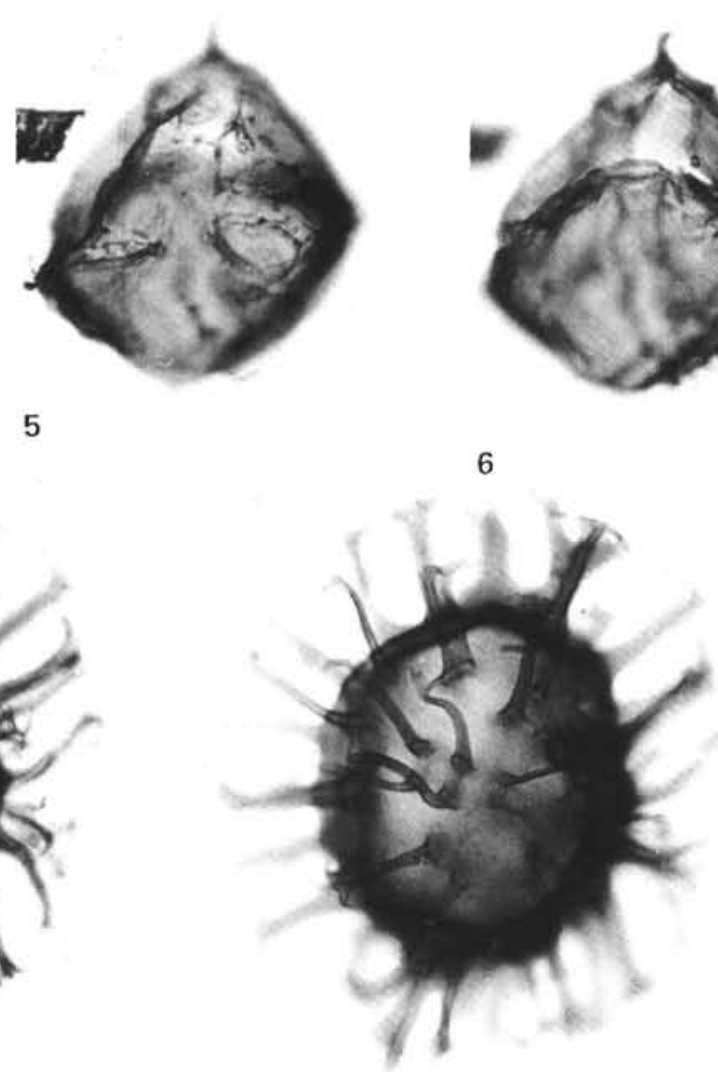

9

6
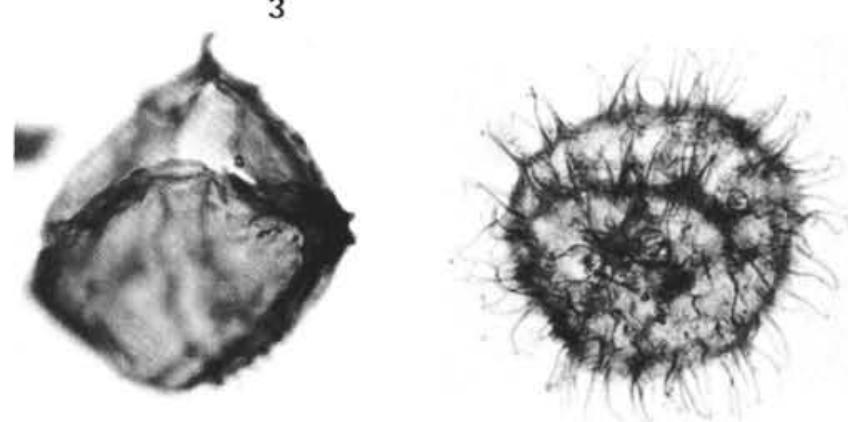

7

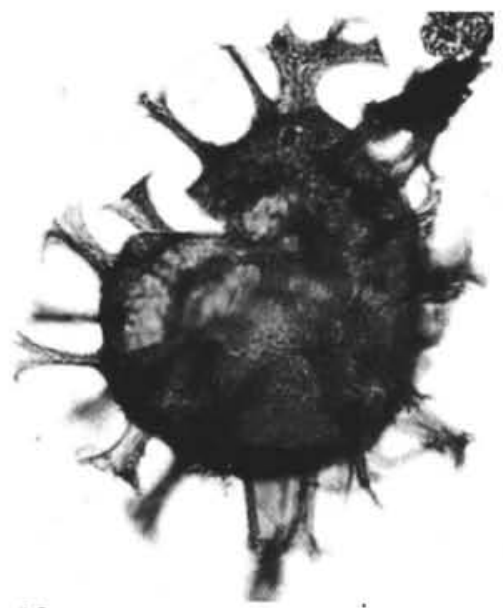

10

Plate 1. Dinoflagellate cysts, $\times 500$ (in addition to the DSDP section, slide number and England Finder Reference are noted). 1, 2. Fibrocysta cf. bipolaris (Cookson and Eisenack) Stover and Evitt; Section 555-44-2; S1; G27/4. 3. Thalassiphora pelagica (Eisenack) Eisenack and Gocht; Section 555-44-2; S2; T54/0. 4, 5, 6. ?Millioudodinium cf. giuseppei (Morgenroth) Stover and Evitt; Section 555-41-4; S1; 047/2. 7. Impletosphaeridium sp. 1; Section 555-67-3; S1; 033/2. 8, 9. Fibrocysta cf. axialis (Eisenack) Stover and Evitt; Section 555-58-1; S1; V58/2. 10. Fibrocysta cf. radiata (Morgenroth) Stover and Evitt; Section 555-54-5; S2; J49/1. 


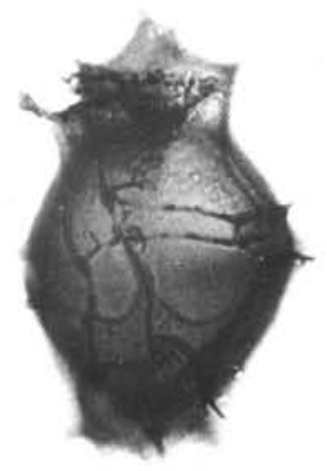

1

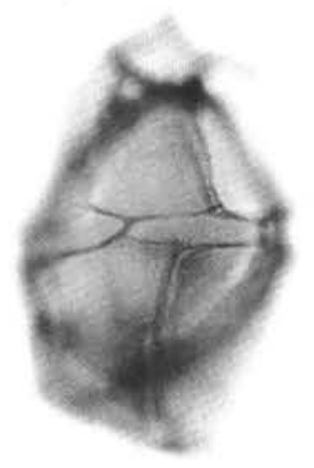

4

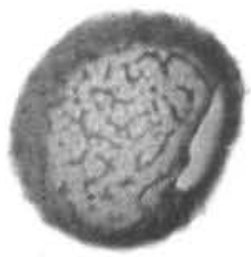

7

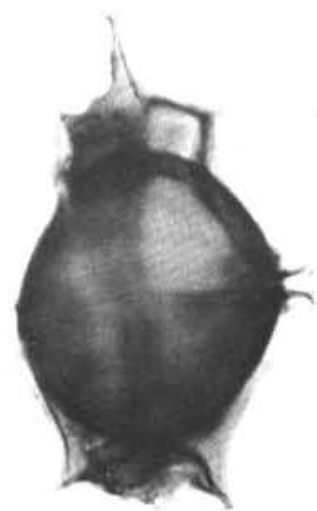

2

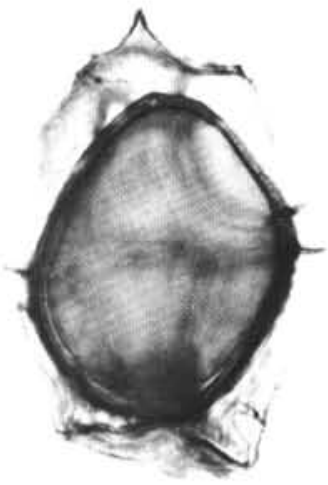

5

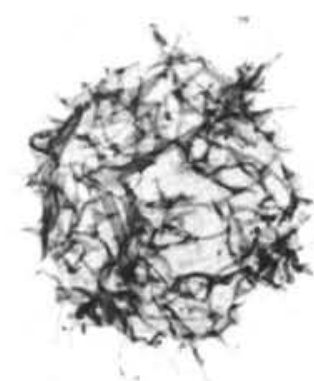

8

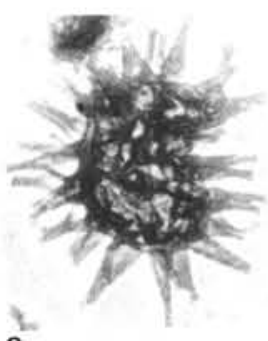

9

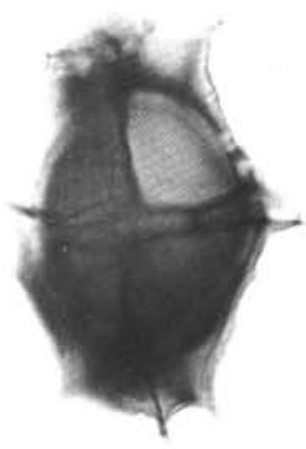

3

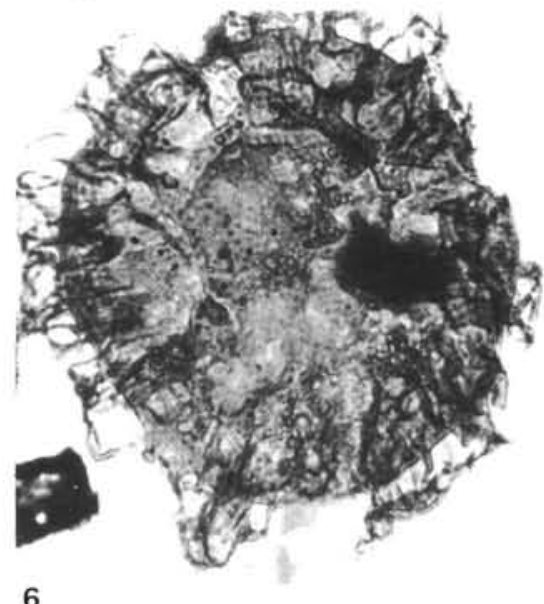

6

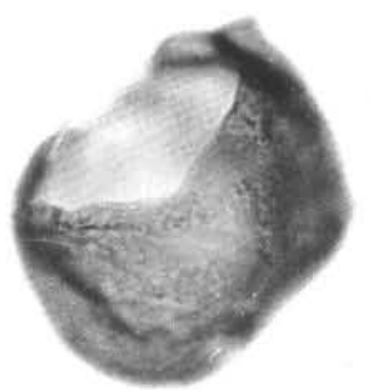

10

Plate 2. Dinoflagellate cysts, $\times 500$ (in addition to the DSDP section, slide number and England Finder Reference are noted). 1, 2, 3. Rottnestia borussica (Eisenack) Cookson and Eisenack; Section 552-18-2; S2; G40/3. 4, 5. ?Impagidinium simplicia (Cookson and Eisenack) Stover and Evitt; Section 552-18-1; S3; E51/1. 6. Glaphyrocysta sp.; Section 555-55-1; S5; H37/2. 7. Cerebrocysta bartonensis Bujak; Section 552-18-2; S1; P42/1. 8. Apectodinium homomorphum (Deflandre and Cookson) Lentin and Williams. 9. Dapsilidinium cf. pastielsii (Davey and Williams) Bujak et al.; Section 553A-11-6; S2; 037/1 (phase contrast). 10. Apteodinium sp.; Section 552-18-1; S1; Y34/0. 

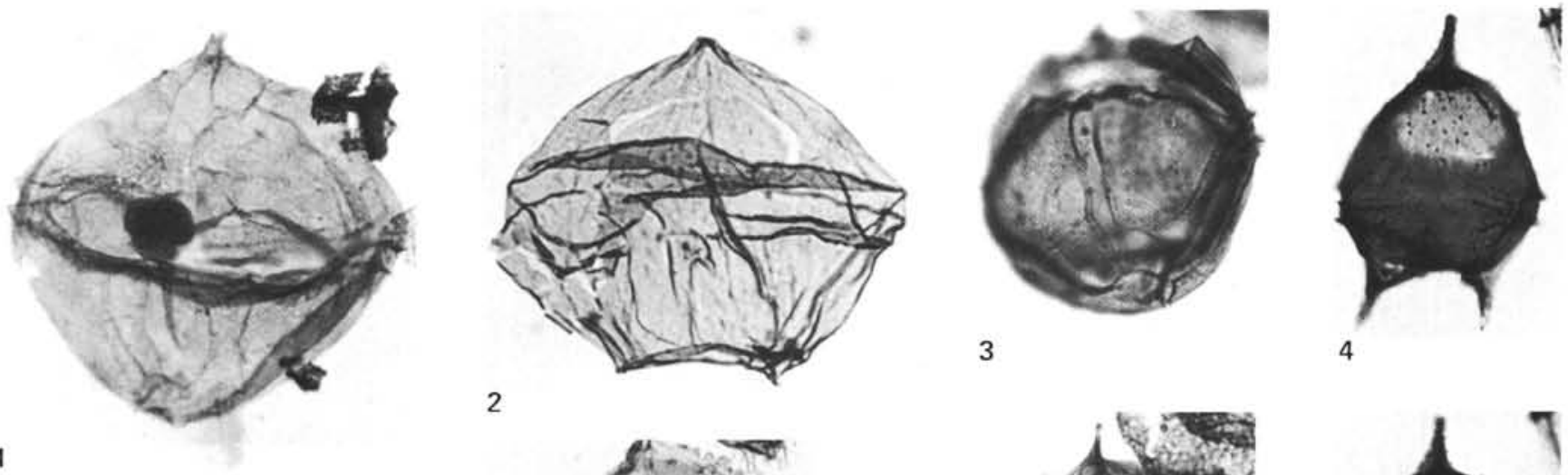

1

2
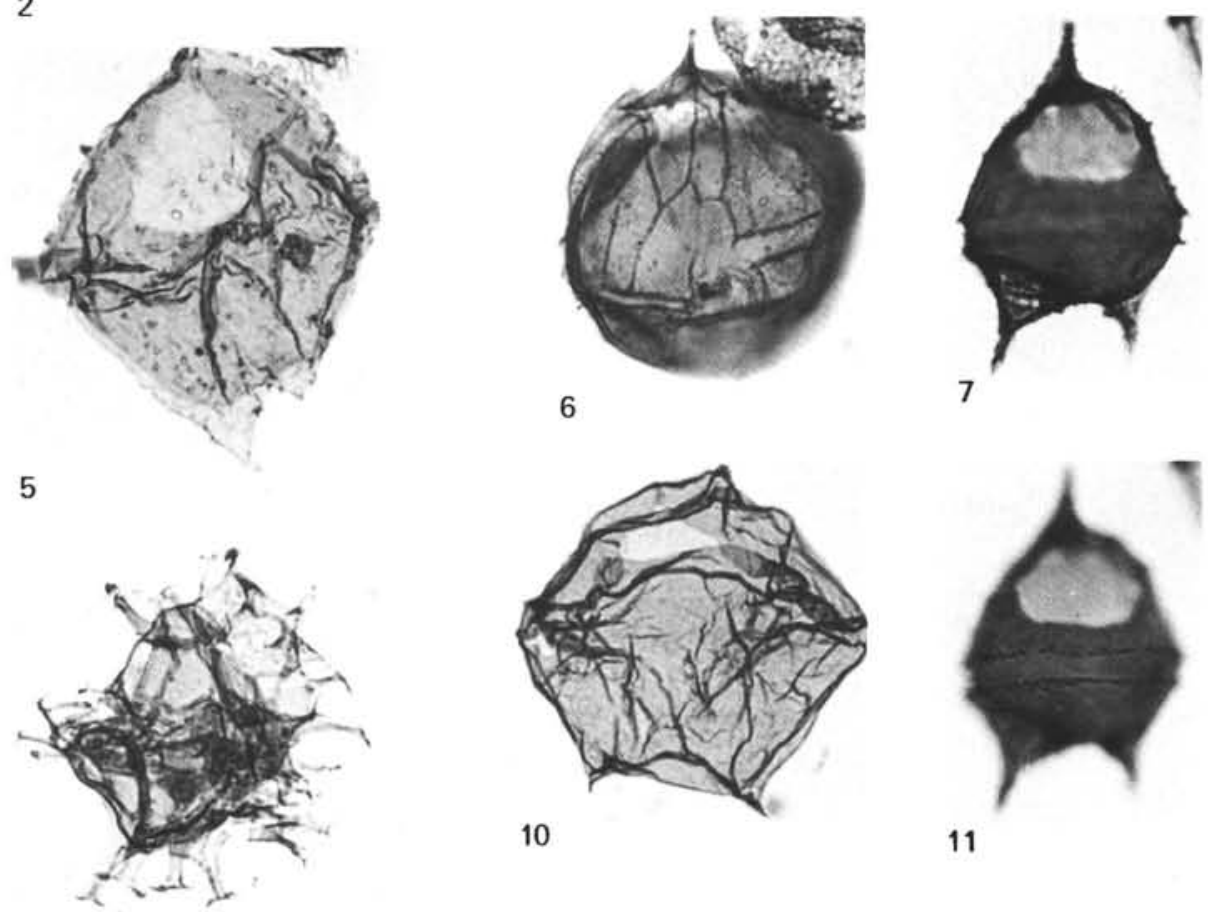

6

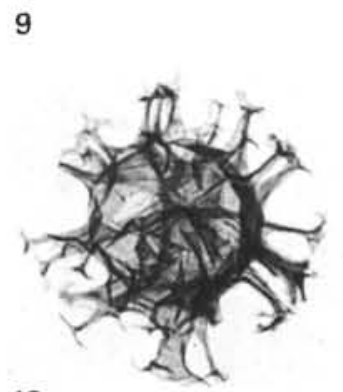

13

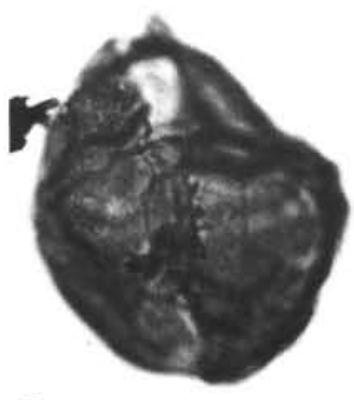

14

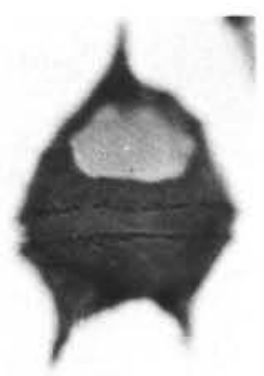

10

11
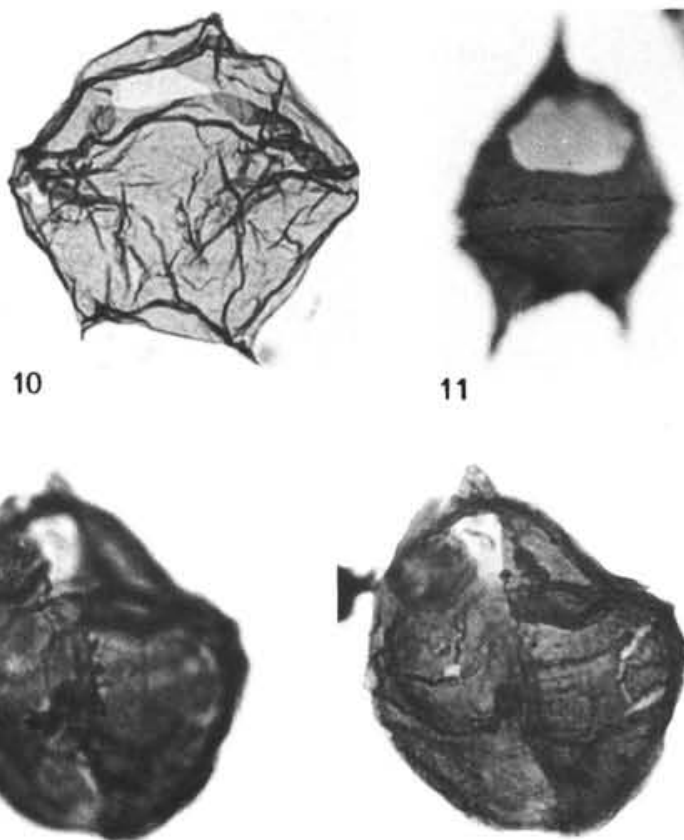

15

Plate 3. Dinoflagellate cysts, $\times 500$ (in addition to the DSDP section, slide number and England Finder Reference are noted). 1. Millioudodinium giuseppei (Morgenroth) Stover and Evitt; Section 553A-37-5; S1; R34/0. 2. Lejeunecysta spatiosa (Morgenroth) Lentin and Williams; Section 553A-24-2; S5; J55/0. 3, 6. Millioudodinium cf. guiseppei (Morgenroth) Stover and Evitt; Section 555-44-2; S1; P49/3. 4, 7, 11. Lentinia serrata Bujak; Section 553A-12-4; S1; H48/3. 5. ? Wetzeliella sp.; Section 555-86-3; S1; W44/2. 8. Deflandrea speciosa forma glabra Gocht; Section 555-88-3; S4; V42/1. 9. Spiniferites membranaceous (Rossignol) Sarjeant; Section 555-47-4; S2; D58/0. 10. Lejeunecysta cf. spatiosa (Morgenroth) Lentin and Williams. 12. ?Adnatosphaeridium sp. 1; Section 555-88-3; S3; D38/2. 13. Spiniferites sp. 1; Section 553A-37-1; S2; J55/3. 14, 15. ?Cribroperidinium sp.; Section 555-44-2; S1; G34/0. 

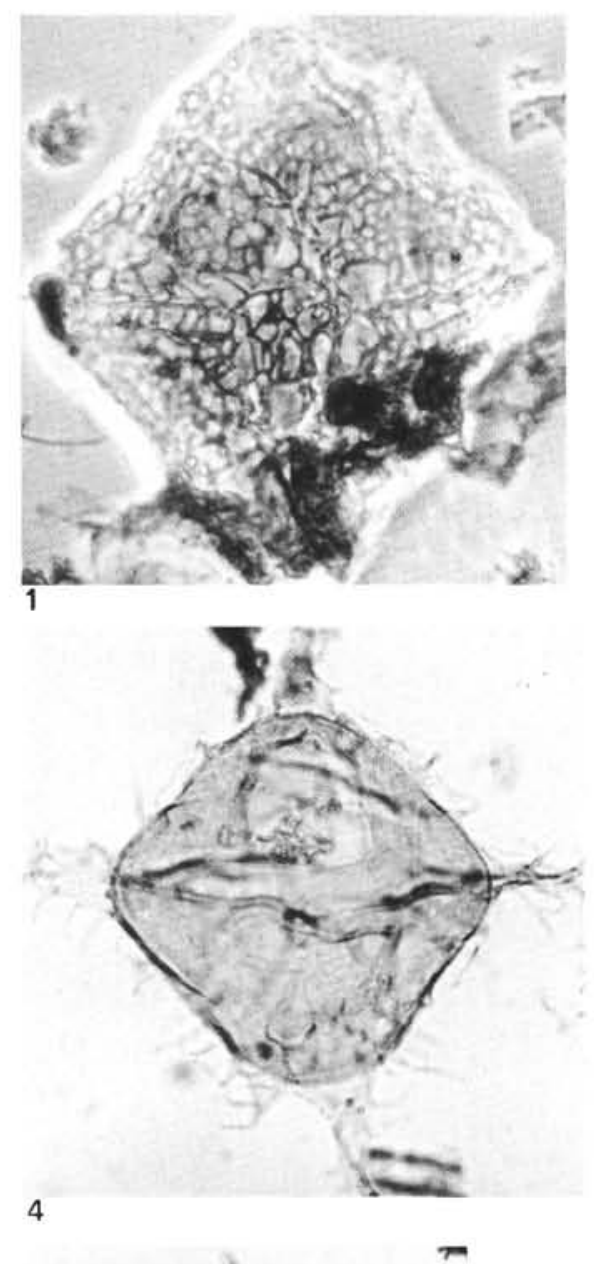
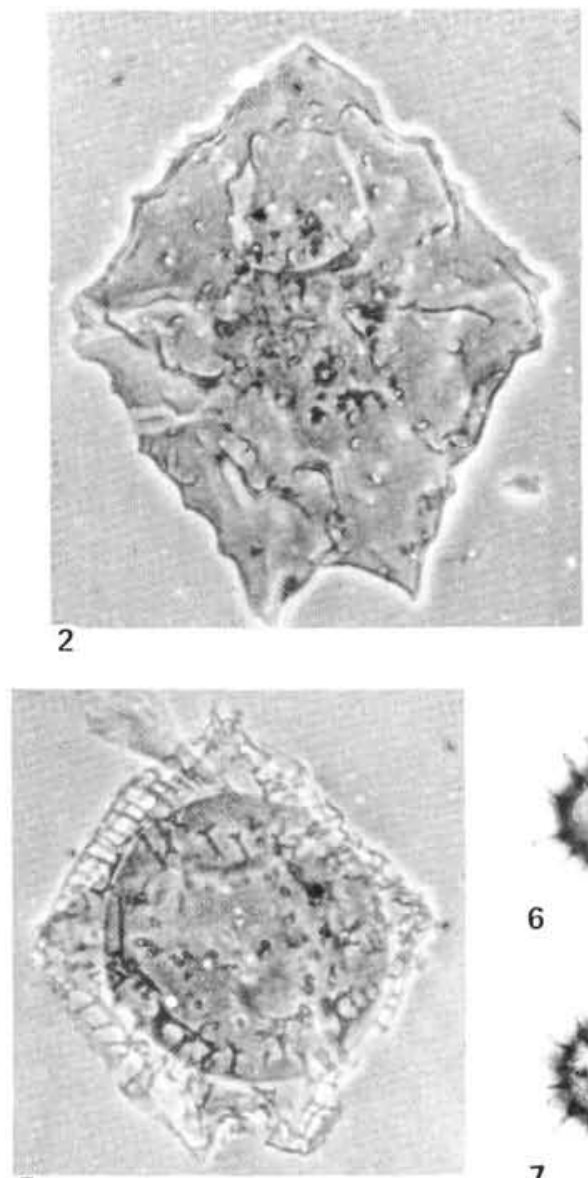

5

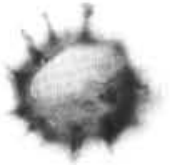

6

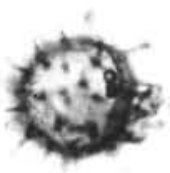

7

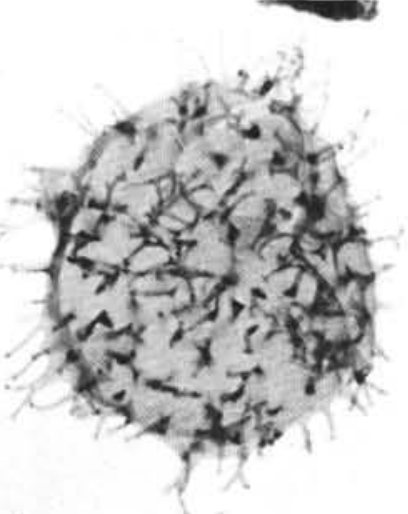

11

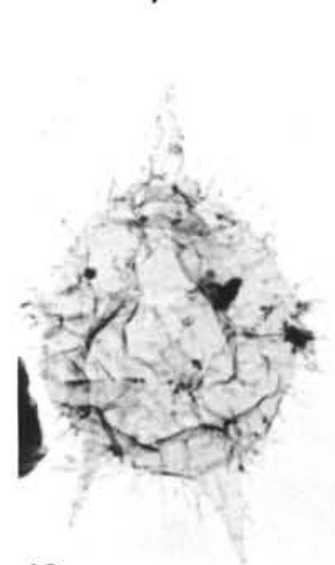

12

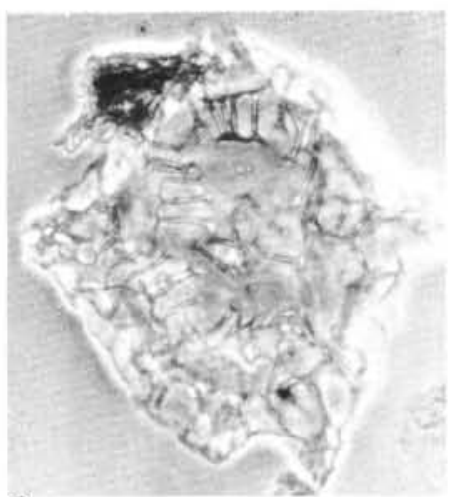

3

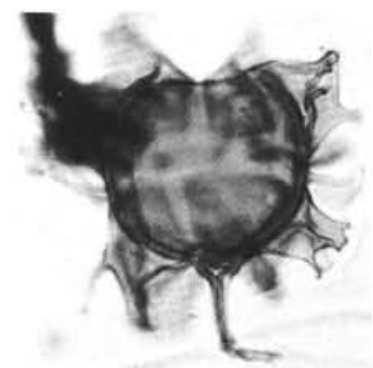

8

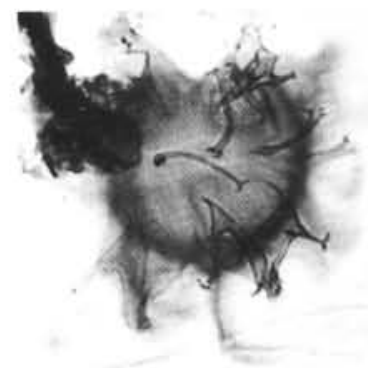

9

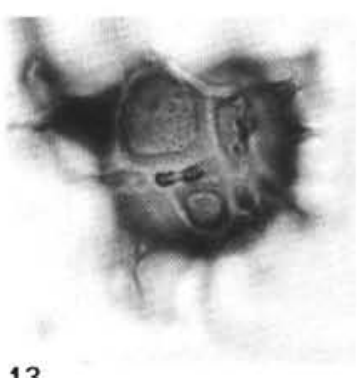

Plate 4. Dinoflagellate cysts, $\times 500$ (in addition to the DSDP section, slide number and England Finder Reference are noted). 1. Kisselovia reticulata (Williams and Downie) Lentin and Williams; Section 552-16-1; S10; T35/2 (phase contrast). 2. Gen. et sp. indet II (cf. Rhombodinium); Section 553A-11-1; S1; M41/0 (phase contrast). 3. Kisselovia cf. clathrata (Eisenack) Lentin and Williams; Section 552-12-6; S2; N57/3 (phase contrast). 4. Wetzeliella similis Eisenack; Section 553A-11-6; S2; T43/1. 5. Kisselovia edwardsii (Wilson) Stover and Evitt; Section 553A-11-1; S2; L41/0 (phase contrast). 6, 7. Gen. et sp. indet. I; Section 555-33-6; S1; V45/4. 8, 9, 13. Hystrichokolpoma cinctum Klumpp; Section 553A-11-6; S2; R57/3. 10. Wetzeliella varilongituda Williams and Downie; Section 553A-11-4; S2; V46/4. 11. Wetzeliella astra Costa et al.; Section 555-60-3; $\mathrm{S} 1 ; \mathrm{F} 46 / 3$. 12. Apectodinium parvum (Alberti) Lentin and Williams; Section 555-86-3; S1; P54/3. 

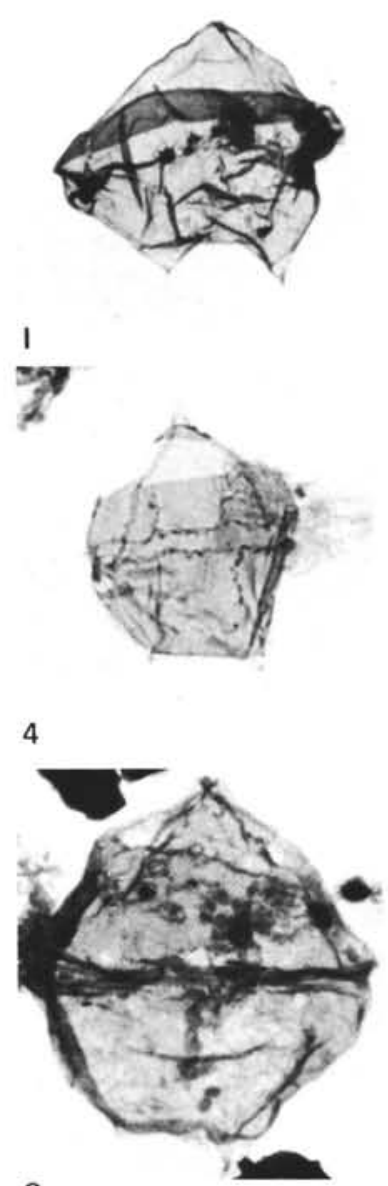

8

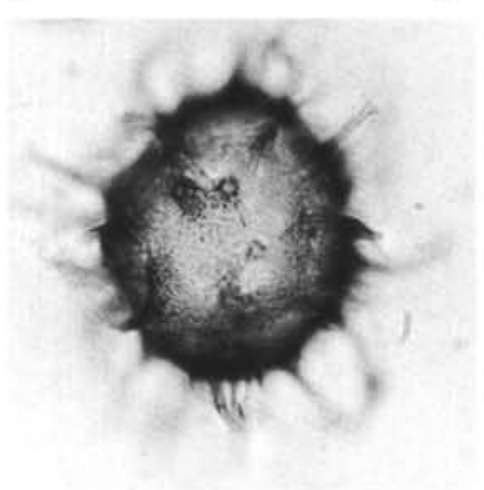

12

2

5

9
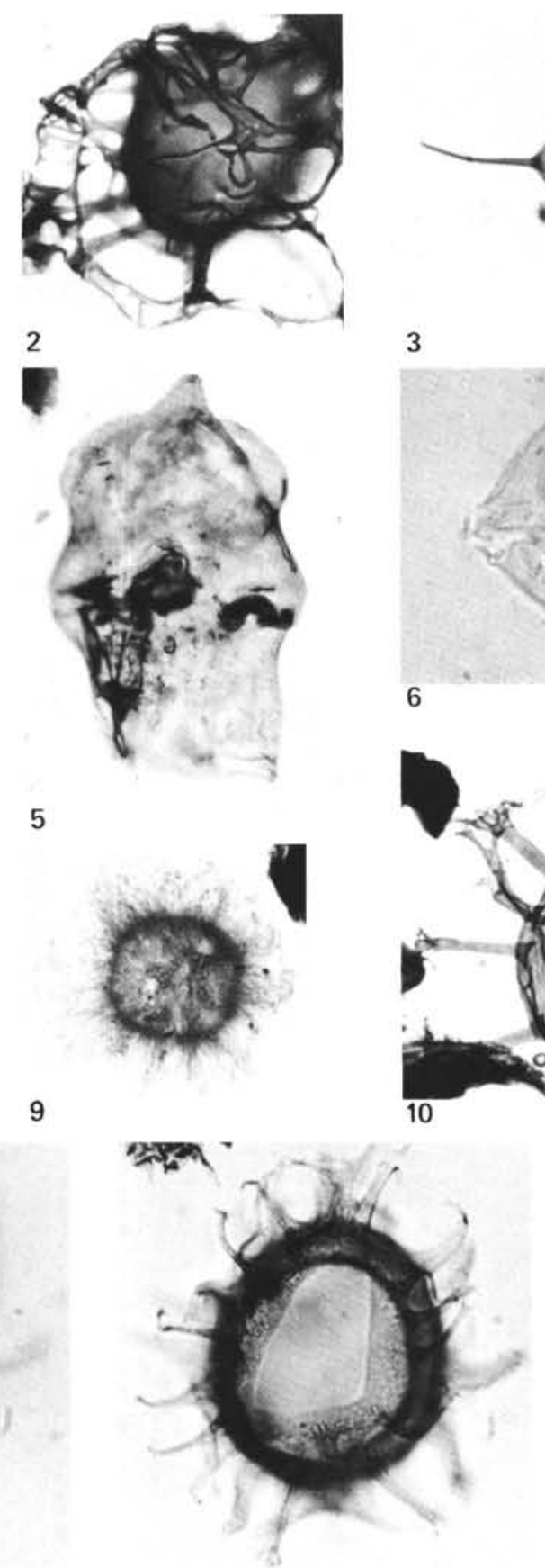

13

3

6
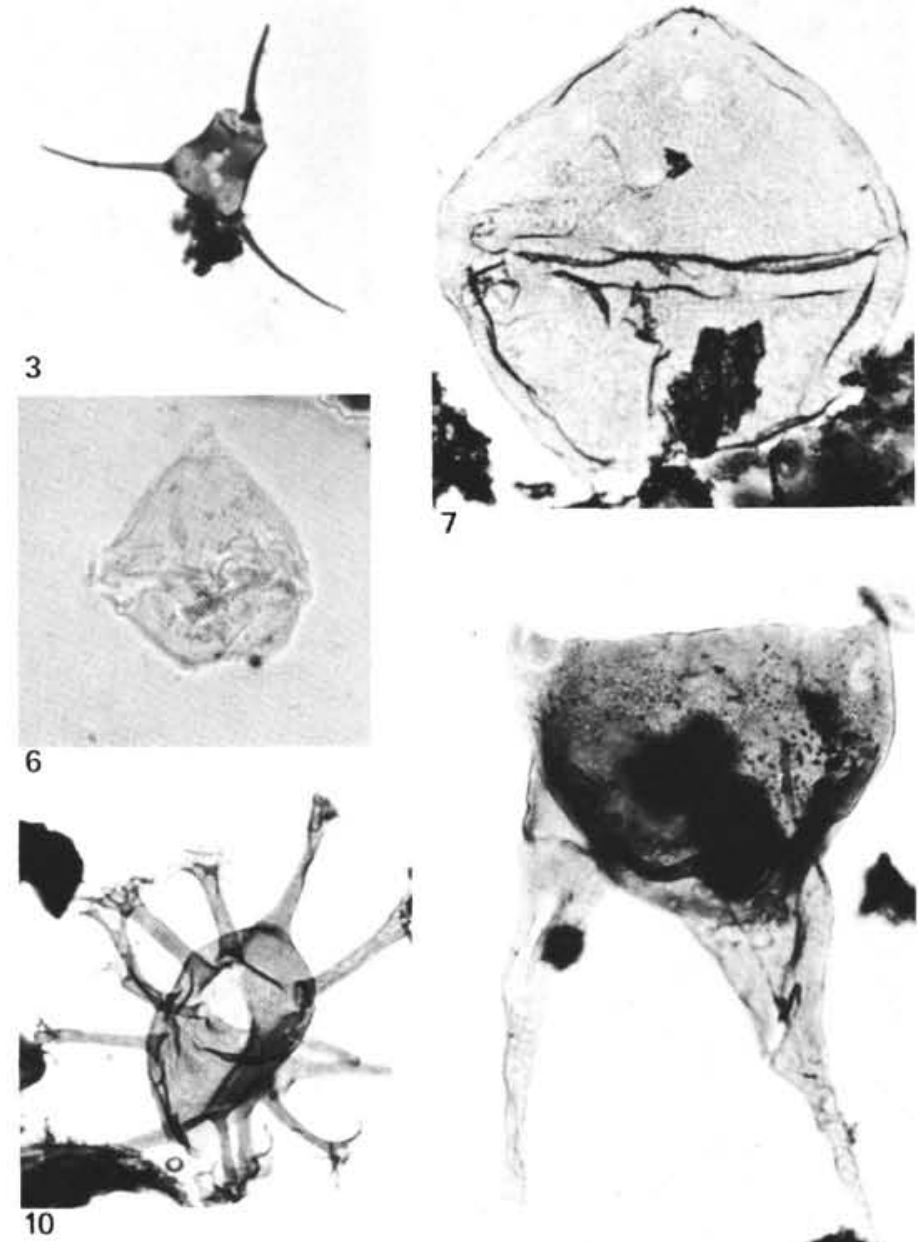

11
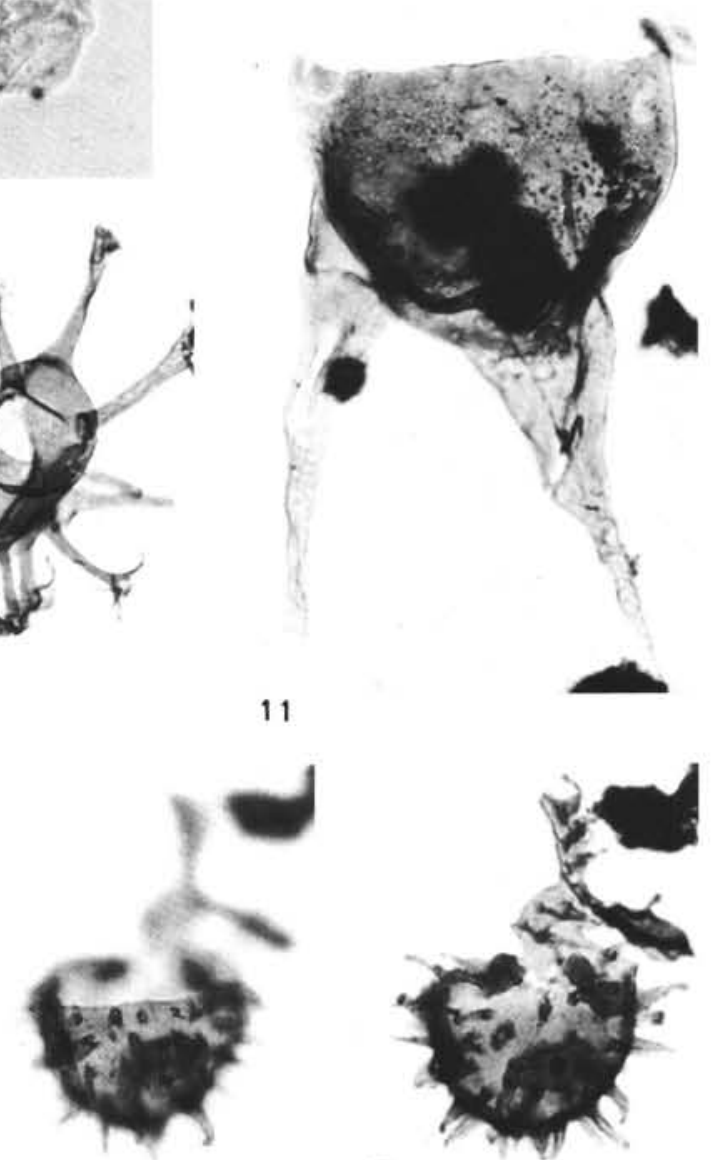

14

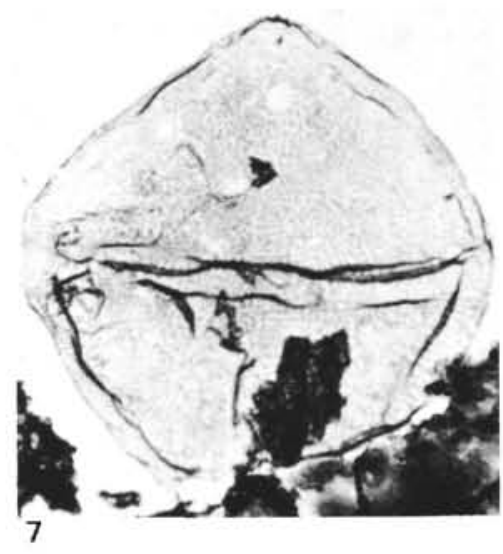

Plate 5. Dinoflagellate cysts, $\times 500$ (in addition to the DSDP section, slide number and England Finder Reference are noted). 1. Lejeunecysta cf. hyalina (Gerlach) Artzner and Dörhöfer; Section 555-44-2; S2; R36/3. 2. ?Nematosphaeropsis sp.; Section 555-53-3; S1; V39/4. 3. Gen. et sp. indet III (acritarch) $\times$ 1000; Section 555-53-3; S4; E43/4. 4. ?Ginginodinium sp. 1; Section 555-62-3; S1; Q52/0. 5. Chatangiella sp. (reworked); Section 555-47-4; S1; Y35/0. 6. ?Senegalinium cf. obscurum (Drugg) Lentin and Williams; Section 555-33-6; S1; G46/0 (phase contact). 7. Palaeoperidinium pyrophorum (Ehrenberg) Sarjeant (reworked); Section 555-52-12; S1; Q56/3. 8. ?Palaeoperidinium sp. (reworked); Section 555-474; S1; W40/0. 9. Comasphaeridium cf. cometes Valensi; Section 555-67-3; S1; G43/0. 10. Oligosphaeridium complex (White) Davey and Williams; Section 555-46-4; S3; V42/0. 11. Odontochitina operculata (Wetzel) Deflandre and Cookson; Section 555-46-4; S3; O45/2. 12, 13. Fibrocysta sp. (cf. Lanternosphaeridium sp. 2, Gocht [1969]); Section 553A-12-4; S1; H52/4. 14, 15. Lingulodinium machaerophorum (Deflandre and Cookson) Wall; Section 555-59-3; S3; L43/3. 